Jacek Żakl, Karolina Orlińskal, Magdalena Koperny ${ }^{2}$, Jarostaw Foremny ${ }^{l}$, Katarzyna Bandoła ${ }^{3}$, Matgorzata Bata ${ }^{4}$

\title{
LEGIONELLA SP. IN WATER SYSTEMS IN PUBLIC TEACHING AND EDUCATION FACILITIES IN MALOPOLSKIE VOIVODESHIP IN 2016
}

\section{LEGIONELLA SP. W INSTALACJACH WODNYCH PLACÓWEK NAUCZANIA I WYCHOWANIA W WOJEWÓDZTWIE MAŁOPOLSKIM W 2016 R.}

\author{
${ }^{1}$ Provincial Sanitary and Epidemiological Station in Krakow \\ ${ }^{2}$ Department of Health Care Benefits The Agency for Health Technology Assessment and Tariff System \\ ${ }^{3}$ District Sanitary-Epidemiological Station in Proszowice \\ ${ }^{4}$ Chair of Epidemiology and Preventive Medicine, Department of Hygiene and Dietetics \\ Jagiellonian University Medical College in Krakow \\ ${ }^{1}$ Wojewódzka Stacja Sanitarno-Epidemiologiczna w Krakowie \\ ${ }^{2}$ Wydział Świadczeń Opieki Zdrowotnej Agencja Oceny Technologii Medycznych i Taryfikacji \\ ${ }^{3}$ Powiatowa Stacja Sanitarno-Epidemiologiczna w Proszowicach \\ ${ }^{4}$ Katedra Epidemiologii i Medycyny Zapobiegawczej, Zakład Higieny i Dietetyki \\ Uniwersytet Jagielloński Collegium Medicum w Krakowie
}

\begin{abstract}
INTRODUCTION. Bacteria Legionella sp. found in water distribution systems, especially warm, transferred to water spray devices for aerators and showers in the form of aerosols infected with them become a threat to the human inhaler.

OBJECTIVE. Assessment of colonization of the water supply network with Legionella bacteria in teaching and education facilities in Małopolska in 2016 year.

MATERIAL AND METHODS. The results of water samples taken from plumbing installations were analyzed in teaching and education facilities by employees of the State Sanitary Inspection of the Lesser Poland Voivodeship.

RESULTS. The results of 366 testing hot water samples in 111 teaching and education centers in Małopolska have shown that in 123 testing samples $(33,6 \%)$ in 48 centers $(43,2 \%)$ the water sample was colonized with Legionella sp. and the water quality did not meet the requirements of the current ordinance of the Minister of Health.

CONCLUSIONS. It is justified to periodically monitor the presence of Legionella sp. in water supply installations in teaching and education centers and taking action to reduce the colonization of these bacteria.
\end{abstract}

Keywords: Legionella sp., legionellosis, legionnaires' disease, Pontiac fever, teaching and education centers

\section{STRESZCZENIE}

WSTĘP. Bakterie Legionella sp. bytujące w systemach dystrybucji wody, zwłaszcza ciepłej, przeniesione do urządzeń rozpylających wodę perlatorów i pryszniców w formie zakażonych nimi aerozoli stają się zagrożeniem dla inhalującego je człowieka.

CEL PRACY. Ocena kolonizacji sieci wodociągowej bakteriami Legionella sp. w placówkach nauczania i wychowania w Małopolsce w $2016 \mathrm{r}$.

MATERIAŁ I METODY. Analizie poddano wyniki badań próbek wody pobranych z instalacji wodociągowych w placówkach nauczania i wychowania przez pracowników Państwowej Inspekcji Sanitarnej województwa małopolskiego.

WYNIKI. Wyniki badań 366 próbek ciepłej wody użytkowej w 111 obiektach nauczania i wychowania na terenie województwa małopolskiego wykazały, iż w 123 próbach $(33,6 \%)$ w 48 obiektach $(43,2 \%)$ była skolonizowana pałeczkami Legionella sp. i jakość wody nie odpowiadała wymaganiom obowiązującego rozporządzenia Ministra Zdrowia.

WNIOSKI. Uzasadnione jest cykliczne monitorowanie obecności pałeczek Legionella sp. w instalacjach wodociągowych obiektów nauczania i wychowania i podejmowanie działań zmierzających do ograniczenia kolonizacji tymi bakteriami.

Słowa kluczowe: Legionella sp., legioneloza, choroba legionistów, goraczka Pontiac, placówki nauczania i wychowania 


\section{INTRODUCTION}

Legionella $\mathrm{sp}$. are found in the aquatic environment, both in natural and artificial reservoirs. In the natural environment they constitute less than $1 \%$ of the total bacterial population and they do not constitute an epidemiological threat (1). The optimal temperature for living and bacterial growth is in the range of 25 $50^{\circ} \mathrm{C}$ (but they also survive at $0-63^{\circ} \mathrm{C}$ ), in $\mathrm{pH} 5,0-8,5$ and with an oxygen content in water of $0.2-15 \mathrm{ppm}$ (2). The growth is favored by low recirculation space in mainly hot water in plumbing installations, blind sections or tips, (called „dead branches" - those in which water stagnation may occur at a distance of more than $3 \mathrm{~m}$ from the risers), in heaters, in water stagnations, places covered with lime sediment, (aerators in taps, showers). What is more, Legionella sp. rods can colonize air conditioners, air humidifiers, fountains and air filters in cars (3) in windshield washer fluid (4) in car washes (5).

Bacteria living in artificial water distribution systems are transferred with small droplets (with a diameter less than $5 \mu \mathrm{m}$ ) generated by devices producing water-air aerosol for example showers, pearl bathtubs, whirlpools, humidifiers, air-conditioning, are becoming the cause of dangerous diseases. The main source of infection is aerosol and fluids and the respiratory tract is the route of infection.

The range of clinical symptoms resulting from pathogenic Legionella infections is wide from asymptomatic infections through the flu-like syndrome to severe pneumonia associated with multi-organ failure (6).

In connection with the entry into force on 11 January 2018 of the revised Ordinance of the Minister of Health of 7 December 2017 on the quality of water intended for human consumption (Journal of Laws of 2017, poz. 2294) the records regarding the obligation to perform hot water tests for the presence of Legionella sp. have changed.

According to current regulations (annex no. 5 to the Regulation mentioned above, Microbiological requirements that hot water should meet, minimum frequency of sampling of hot water and procedures depending on the results of the bacteriological examination), such tests should also be carried out in public buildings, in which a water and air aerosol is generated during their use. Until now, this obligation concerned only buildings of collective residence and enterprises of the entity performing medical activities such as stationary and round-the-clock health services (7).

In the present study, only a group of objects of education and upbringing was analyzed (hereinafter: teaching and upbringing) defined in accordance with Report MZ-53 on hygiene activities for children and youth to which we include: nurseries and children's 228

\section{WSTĘP}

Pałeczki Legionella sp. występują w środowisku wodnym, zarówno w naturalnych, jak i sztucznych rezerwuarach. W środowisku naturalnym stanowią mniej niż 1\% ogólnej populacji bakterii i nie stanowią zagrożenia epidemiologicznego (1). Optymalna temperatura do życia i rozwoju bakterii mieści się w przedziale $25-$ $50^{\circ} \mathrm{C}$, ale przeżywają nawet $\mathrm{w}$ temperaturze $0-63^{\circ} \mathrm{C}$, w pH 5,0-8,5 oraz przy zawartości tlenu w wodzie $0,2-15$ ppm (2). Rozwojowi sprzyjają miejsca o niskiej recyrkulacji głównie ciepłej wody w instalacjach wodociągowych, ślepych odcinkach lub końcówkach (tzw. „martwe odgałęzienia” - tj. takie, w których mogą wystąpić zastoiska wody w odległości większej niż $3 \mathrm{~m}$ od pionów), w podgrzewaczach, zasobnikach, miejscach pokrytych osadem wapiennym (perlatory w bateriach, prysznice). Ponadto pałeczki Legionella sp. mogą kolonizować klimatyzatory, nawilżacze powietrza, fontanny, a także filtry powietrza w samochodach (3) w płynie do spryskiwaczy (4) oraz w myjniach samochodowych (5).

Bakterie bytując w sztucznych systemach dystrybucji wody przenoszone są za pomocą drobnych kropelek (o średnicy mniejszej niż $5 \mu \mathrm{m}$ ) wytwarzanych przez urządzenia produkujące aerozol wodno-powietrzny, tj.: prysznice, wanny perełkowe, jacuzzi, nawilżacze powietrza, klimatyzacje i stają się przyczyną niebezpiecznych chorób. Głównym źródłem zakażenia jest aerozol oraz płyny, a drogą zakażenia są drogi oddechowe.

Zakres objawów klinicznych będących następstwem zakażeń patogennymi Legionella jest szeroki, poczynając od bezobjawowych infekcji poprzez zespół grypopodobny do ciężkiego zapalenia płuc połączonego z niewydolnością wielonarządową (6).

W związku z wejściem w życie w dniu 11 stycznia 2018 r. znowelizowanego rozporządzenia Ministra Zdrowia z dnia 7 grudnia 2017 r. w sprawie jakości wody przeznaczonej do spożycia przez ludzi (Dz. U. 2017, poz. 2294) zmianie uległy m.in. zapisy dotyczące obowiązku wykonywania badań wody ciepłej pod kątem obecności bakterii Legionella sp. Zgodnie z aktualnymi regulacjami (załącznik nr 5 do ww. rozporządzenia Wymagania mikrobiologiczne, jakim powinna odpowiadać ciepta woda, minimalna częstotliwość pobierania próbek ciepłej wody oraz procedury postępowania $w$ zależności od wyników badania bakteriologicznego), badania takie należy wykonywać również w budynkach użyteczności publicznej, w których w trakcie ich użytkowania wytwarzany jest aerozol wodno-powietrzny. Dotychczas obowiązek ten dotyczył jedynie budynków zamieszkania zbiorowego i przedsiębiorstw podmiotu wykonującego działalność leczniczą w rodzaju stacjonarne i całodobowe świadczenia zdrowotne (7).

W niniejszej pracy analizie poddano wyłącznie grupę obiektów oświaty i wychowania (dalej: nauczania i wychowania) definiowanych zgodnie ze Sprawozdaniem MZ-53 z działalności w zakresie higieny dzieci i mło- 
clubs, kindergartens and other forms of pre-school education, junior high schools, general secondary schools, secondary professional schools, special and post-secondary schools, school complexes, school workshops, hostels and boarding schools, continuing education institutions, universities, institutions with stays round-the-clock, care and education centers, day care, out-of-school centers, recreation facilities.

In the light of the applicable law there is a need to monitor water for the presence of Legionella sp. in mentioned above teaching and upbringing centers in order to take rational preventive actions minimizing the potential effects of health hazards caused by microbiological contamination of hot water installations mentioned above bacteria. Ordinance of the Minister of Health of 7 December 2017 on the quality of water intended for human consumption (Journal of Laws of 2017, item 2294) determines places, minimum frequency of sampling of hot water and the rules for further proceedings depending on the obtained results of microbiological tests (Table I). dzieży, do których zaliczamy: żłobki i kluby dziecięce, przedszkola i inne formy wychowania przedszkolnego, gimnazja, licea ogólnokształcące, ponadgimnazjalne szkoły zawodowe, szkoły specjalne i policealne, zespoły szkół, warsztaty szkolne, bursy i internaty, placówki kształcenia ustawicznego, szkoły wyższe, placówki z pobytem całodobowym, placówki opiekuńczo-wychowawcze, wsparcia dziennego, placówki wychowania pozaszkolnego, placówki rekreacyjne.

W świetle obowiązujących przepisów prawa wskazać należy na konieczność prowadzenia monitoringu wody pod kątem obecności bakterii Legionella sp. w ww. obiektach nauczania i wychowania $\mathrm{w}$ celu podejmowania racjonalnych działań prewencyjnych, minimalizujących potencjalne skutki zagrożenia zdrowotnego wywołanego skażeniem mikrobiologicznym instalacji ciepłej wody ww. bakterią. Rozporządzenie Ministra Zdrowia z dnia 7 grudnia 2017 r. w sprawie jakości wody przeznaczonej do spożycia przez ludzi (Dz. U. 2017, poz. 2294) określa miejsca, minimalną częstotliwość pobierania próbek ciepłej wody oraz zasady dalszego postępowania w zależności od uzyskanych wyników badań mikrobiologicznych (Tab. I).

Table I. Frequency of sampling hot water and procedures depending on the results of the bacteriological test along with the assessment of contamination with Legionella sp.

Tabela I. Częstotliwość pobierania próbek ciepłej wody oraz procedury postępowania w zależności od wyników badania bakteriologicznego wraz z oceną skażenia drobnoustrojami Legionella sp.

\begin{tabular}{|c|c|c|c|}
\hline $\begin{array}{c}\text { Number } \\
\text { Legionella sp. }\end{array}$ & $\begin{array}{l}\text { Evaluation of } \\
\text { contamination }\end{array}$ & Procedure & Frequency of testing \\
\hline$<100 / 100 \mathrm{ml}$ & $\begin{array}{c}\text { None } \\
\text { or negligible }\end{array}$ & $\begin{array}{l}\text { The system is under control - it does not } \\
\text { require any special actions to be taken. }\end{array}$ & After 1 year \\
\hline$\geq 100 / 100 \mathrm{ml}$ & Average & $\begin{array}{l}\text { If most of the samples are positive, the water } \\
\text { should be considered colonized by Legionella } \\
\text { sp., find the cause (review the technical network, } \\
\text { check the temperature of the water) and take } \\
\text { measures to reduce the number of bacteria. } \\
\text { Further distances (cleaning and disinfection) } \\
\text { depend on the result of the next test. }\end{array}$ & $\begin{array}{l}\text { After } 4 \text { weeks, if the test } \\
\text { result does not change, } \\
\text { clean and disinfect, perform } \\
\text { the test after } 1 \text { week, then } \\
\text { after } 1 \text { year. }\end{array}$ \\
\hline$\geq 1000 / 100 \mathrm{ml}$ & High & $\begin{array}{l}\text { Intervention measures should be initiated } \\
\text { including cleaning and disinfection of the } \\
\text { system - the water is not suitable for showers. }\end{array}$ & $\begin{array}{l}\text { After } 1 \text { week of cleaning } \\
\text { and disinfection, then every } \\
3 \text { months }\end{array}$ \\
\hline$\geq 10000 / 100 \mathrm{ml}$ & Very high & $\begin{array}{l}\text { Immediately switch off the device and install } \\
\text { hot water and carry out the cleaning of the } \\
\text { sanitizing procedures. }\end{array}$ & $\begin{array}{l}\text { After } 1 \text { week of cleaning } \\
\text { and disinfection, then every } \\
3 \text { months }\end{array}$ \\
\hline
\end{tabular}

According to the regulations, the obligation to perform hot water tests of the Legionella sp. parameter in educational and upbringing centers rests with the school authority (most often these are local government authorities). The authorities of the State Sanitary Inspection do not carry out such tests for this category of centers.
Zgodnie z przepisami obowiązek wykonywania badań ciepłej wody użytkowej parametru Legionella sp. w obiektach oświaty i wychowania spoczywa na organie prowadzącym (najczęściej są to władze samorządowe). Organy Państwowej Inspekcji Sanitarnej nie wykonują badań w powyższym zakresie dla tej kategorii obiektów. 


\section{THE AIM OF THE STUDY}

Assessment of colonization of the water supply network with Legionella bacteria in teaching and education facilities in Małopolska in 2016 year. It should be emphasized that no one has ever conducted research so far in this type of public facilities in Poland and thus there is no available research literature addressing this problem.

\section{MATERIAL AND METHODS}

The results of tests of samples taken in educational and upbringing facilities were analyzed by employees of the State Sanitary Inspection of the Lesser Poland Voivodeship. The samples were tested in an accredited laboratory (Nr AB 601) Provincial Sanitary and Epidemiological Station in Krakow. Water quality control in the presence of $L e-$ gionella $\mathrm{sp}$. in these facilities was part of the activities related to the preparations for the World Youth Day, which took place on July 25-31, 2016 in Krakow. Pilgrims were accommodated in facilities located in the poviats (Myślenice, Nowy Targ, Kraków and the poviat of the City of Kraków, Limanowa, Wieliczka, Oświęcim, Nowy Sącz, Zakopane, Chrzanów, Bochnia, Brzesko, Tarnów, Wadowice and Proszowice). Due to the need to ensure proper sanitary protection of public facilities designated as accommodation for public pilgrims it was justified to test the water for the presence of Legionella sp. in showers in hygienic and sanitary rooms before the arrival of guests and, if necessary, take effective preventive actions to eliminate the bacteria. The study covered objects such as: primary schools, junior high school, post-secondary school, upper secondary school, dormitories and boarding school, professional education centers, student houses, inter-school sports centers, youth cultural center and youth palace, youth educational center, special educational and educational centers (Tab II).

\section{CEL PRACY}

Celem pracy jest ocena kolonizacji sieci wodociągowej bakteriami Legionella sp. w placówkach nauczania i wychowania w Małopolsce w 2016 r. Należy podkreślić, iż jak dotąd nikt wcześniej nie prowadził badań w tego typu obiektach użyteczności publicznej w Polsce i tym samym brak jest dostępnej literatury badawczej podejmującej ten problem.

\section{MATERIAŁY I METODY}

Analizie poddano wyniki badań próbek pobranych w placówkach nauczania i wychowania przez pracowników Państwowej Inspekcji Sanitarnej województwa małopolskiego. Próbki zostały przebadane w akredytowanym laboratorium (Nr AB 601) Wojewódzkiej Stacji Sanitarno-Epidemiologicznej w Krakowie.

Kontrola jakości wody na obecność Legionella sp. w tych obiektach wchodziła w zakres działań związanych z przygotowaniami do Światowych Dni Młodzieży (ŚDM), które odbyły się w dniach 25-31 lipca 2016 r. w Krakowie. Pielgrzymi zakwaterowani zostali w obiektach zlokalizowanych na terenie powiatów (myślenickiego, nowotarskiego, krakowskim i powiat Miasto Kraków, w powiatach limanowskim, wielickim, oświęcimskim, suskim, tartrzańskim, chrzanowskim, bocheńskim, brzeskim, tarnowskim, wadowickim, proszowickim). Ze względu na konieczność zapewnienia właściwego zabezpieczenia sanitarnego obiektów użyteczności publicznej wyznaczonych jako miejsca noclegowe dla pielgrzymów, uzasadnione było badanie wody na obecność bakterii Legionella sp. w natryskach $\mathrm{w}$ pomieszczeniach higieniczno-sanitarnych przed przybyciem gości i ewentualne podjęcie skutecznych działań naprawczych eliminujących bakterię.

Table II. Percentage of facilities tested in individual categories to the number of all registered buildings in the małopolskie voivodship Tabela II. Procent obiektów kontrolowanych w poszczególnych kategoriach wobec liczby wszystkich obiektów zarejestrowanych w województwie małopolskim

\begin{tabular}{|l|c|c|c|}
\hline $\begin{array}{c}\text { Object type according to the classification } \\
\text { of the MZ-53 reporting report }\end{array}$ & $\begin{array}{c}\text { The number of facilities in which } \\
\text { water samples were taken }\end{array}$ & $\begin{array}{c}\text { The number of objects } \\
\text { registered in the province }\end{array}$ & $\begin{array}{c}\text { \% } \\
\text { inspected } \\
\text { facilities }\end{array}$ \\
\hline dormitories and boarding school & 7 & 29 & $24 \%$ \\
\hline proffesional education centers & 2 & 14 & $14 \%$ \\
\hline student houses & 17 & 57 & $30 \%$ \\
\hline junior high schools & 2 & 6 & $4 \%$ \\
\hline inter-school sports centers & 1 & 89 & $33 \%$ \\
\hline youth cultural centers and youth palaces & 1 & 4 & $1 \%$ \\
\hline youth educational centers & 2 & 30 & $25 \%$ \\
\hline $\begin{array}{l}\text { special educational and upbringing } \\
\text { centers }\end{array}$ & 31 & 857 & $7 \%$ \\
\hline primary schools & 1 & 115 & $4 \%$ \\
\hline post-secondary schools & 37 & 776 & $1 \%$ \\
\hline upper secondary school & $\mathbf{1 1 1}$ & $\mathbf{2 1 2 9}$ & $5 \%$ \\
\hline Summary & $\mathbf{5}$ & $24 \%$ \\
\hline
\end{tabular}


The following hot water sampling sites were selected, allowing assessment of the internal water supply network in the area of Legionella sp. contamination in public buildings:

1) outflow from the hot water tank or the nearest intake point;

2) the intake point furthest from the hot water tank;

3) place of water returning to the heater;

4) selected intermediate points, the number of which depends on the size of the system.

The samples were collected by certified water samplers, employees of the State Sanitary Inspection of the Lesser Poland Voivodeship. The tests were carried out in accordance with the standard PN-EN ISO 11731-2:2008.

\section{RESULTS}

In 2016, in selected educational and upbringing facilities in the Lesser Poland voivodship 366 samples of domestic hot water were collected in 111 facilities. The test results showed that in 123 samples (33.6\%) in 48 facilities $(43.2 \%)$, water quality did not meet the requirements of the current regulation of the Minister of Health (8) (Tab. III).
Badaniem objęto obiekty takie jak: szkoły podstawowe, gimnazja, szkoła policealna, zespoły szkół, bursy i internaty, centra kształcenia zawodowego, domy studenckie, międzyszkolne ośrodki sportowe, młodzieżowy dom kultury i pałac młodzieży, młodzieżowy ośrodek wychowawczy, specjalne ośrodki szkolno-wychowawcze (Tabela II).

Wytypowano następujące miejsca pobierania próbek ciepłej wody, pozwalające na ocenę wewnętrznej instalacji wodociągowej w zakresie skażenia bakteriami Legionella sp. w budynkach użyteczności publicznej:

1) wypływ ze zbiornika ciepłej wody lub najbliższy punkt czerpalny;

2) punkt czerpalny najdalej położony od zbiornika ciepłej wody;

3) miejsce powrotu wody do podgrzewacza;

4) wybrane punkty pośrednie, których liczba zależała od wielkości systemu.

Próbki zostały pobrane przez certyfikowanych próbkobiorców wody, pracowników Państwowej Inspekcji Sanitarnej województwa małopolskiego. Badania przeprowadzono zgodnie z normą PN-EN ISO 11731-2:2008.

Table III. Number of hot water samples tested in individual facilities

Tabela III. Liczba próbek ciepłej wody przebadanych w poszczególnych obiektach

\begin{tabular}{|c|c|c|c|c|}
\hline The type of facilities & $\begin{array}{l}\text { Facility Type According to } \\
\text { the MZ-53 classification }\end{array}$ & $\begin{array}{c}\text { Number of samples } \\
\text { warmer water in which } \\
\text { Legionella } \text { sp. bacteria } \\
\text { were detected. }\end{array}$ & $\begin{array}{c}\text { Number of } \\
\text { all hot water } \\
\text { samples tested }\end{array}$ & $\%$ \\
\hline \multicolumn{2}{|c|}{ Institutions of the lifelong education } & & 5 & $0.00 \%$ \\
\hline \multirow{2}{*}{$\begin{array}{l}\text { Institutions of the after school } \\
\text { upbringing }\end{array}$} & inter-school sports centres & & 7 & $0.00 \%$ \\
\hline & $\begin{array}{l}\text { youth cultural centers and } \\
\text { youth palaces }\end{array}$ & 1 & 3 & $33.33 \%$ \\
\hline \multicolumn{2}{|c|}{ Institutions of the after school upbringing } & 1 & 10 & $10.00 \%$ \\
\hline \multirow{4}{*}{ Facilities with the 24-hour stay } & $\begin{array}{l}\text { dormitories and boarding } \\
\text { school }\end{array}$ & 9 & 23 & $39.13 \%$ \\
\hline & student houses & 22 & 67 & $32.84 \%$ \\
\hline & youth educational centers & 3 & 13 & $23.08 \%$ \\
\hline & \begin{tabular}{|l} 
special educational and \\
upbringing centers
\end{tabular} & 5 & 7 & $71.43 \%$ \\
\hline \multicolumn{2}{|l|}{ Institutions with the 24-hour stay } & 39 & 110 & $35.45 \%$ \\
\hline \multirow{3}{*}{$\begin{array}{l}\text { Functioning independently } \\
\text { schools }\end{array}$} & junior high schools & 19 & 36 & $52.78 \%$ \\
\hline & primary schools & 24 & 96 & $25.00 \%$ \\
\hline & post-secondary schools & 4 & 4 & $100.00 \%$ \\
\hline \multicolumn{2}{|c|}{ Functioning independently schools } & 47 & 136 & $34.56 \%$ \\
\hline \multicolumn{2}{|l|}{ School teams } & 36 & 105 & $34.29 \%$ \\
\hline & Final sum: & 123 & 366 & $33.61 \%$ \\
\hline
\end{tabular}

Table III of the data submitted shows that the largest number of samples, in which Legionella sp. were detected in facilities with the 24-hour stay in functioning independently schools and school teams. Taking into account specific categories of facilities excluding facilities where only one sample was taken, the highest percent-

\section{WYNIKI}

W 2016 r. w wytypowanych placówkach nauczania i wychowania na terenie województwa małopolskiego pobrano 366 próbek ciepłej wody użytkowej w 111 obiektach. Wyniki badań wykazały, iż w 123 
age of colonization of water supply network was found in junior high schools $(70 \%)$, dormitories and boarding schools $(57,1 \%)$ and student houses $(47,1 \%)$. The Table IV shows the percentage of objects in terms of the presence of Legionella sp. together with the assessment of contamination in individual categories of teaching and upbringing facilities. In terms of the degree of contamination (none or negligible, medium, high, very high parameters specified in Table I of the Regulation (9) the highest number of samples questioned fell within the scope of medium contamination (74 samples), 39 samples of high contamination and 10 very high samples (in 4 objects, the number of Legionella spp. bacteria found was $10,000 \mathrm{cfu} / 100 \mathrm{ml}$ ). In 243 samples the number of Legionella sp. was negligible or bacteria did not occur. próbach $(33,6 \%)$ w 48 obiektach (43,2\%) jakość wody nie odpowiadała wymaganiom obowiązującego rozporządzenia Ministra Zdrowia (8) (Tabela III)

Z przedstawionych w Tabeli III danych wynika, że największą liczbę próbek, w których wykryto pałeczki Legionella sp. pobrano w placówkach z pobytem całodobowym, w szkołach funkcjonujących samodzielnie i zespołach szkół.

Biorąc pod uwagę konkretne kategorie obiektów z wyłączeniem obiektów, w których pobrano tylko jedną próbkę, najwyższy odsetek kolonizacji sieci wodociągowej stwierdzono w gimnazjach $(70 \%)$, bursach i internatach $(57,1 \%)$ oraz domach studenckich $(47,1 \%)$.

Table IV. Percentage of objects where Legionella sp. was detected and assessment of contamination in particular categories Tabela IV. Procent obiektów, w których wykryto obecności Legionella sp. wraz z oceną skażenia w poszczególnych kategoriach obiektów

\begin{tabular}{|c|c|c|c|c|c|c|c|c|c|}
\hline \multirow{3}{*}{ Rodzaj obiektu } & \multirow{3}{*}{$\begin{array}{c}\text { Procent } \\
\text { obiektów } \\
\text { w których } \\
\text { wykryto } \\
\text { Legionellę }\end{array}$} & \multicolumn{2}{|c|}{$\begin{array}{l}\text { Brak lub } \\
\text { znikome }\end{array}$} & \multicolumn{2}{|c|}{ Średnie } & \multicolumn{2}{|c|}{ Wysokie } & \multicolumn{2}{|c|}{ Bardzo wysokie } \\
\hline & & \multicolumn{2}{|c|}{$<100 \mathrm{jtk} / 100 \mathrm{ml}$} & \multicolumn{2}{|c|}{$\geq 100 \mathrm{jtk} / 100 \mathrm{ml}$} & \multicolumn{2}{|c|}{$\geq 1000 \mathrm{jtk} / 100 \mathrm{ml}$} & \multicolumn{2}{|c|}{$\geq 10000 \mathrm{jtk} / 100 \mathrm{~m}$} \\
\hline & & $\begin{array}{l}\text { Liczba } \\
\text { próbek }\end{array}$ & $\%$ & $\begin{array}{l}\text { Liczba } \\
\text { próbek }\end{array}$ & $\%$ & $\begin{array}{l}\text { Liczba } \\
\text { próbek }\end{array}$ & $\%$ & $\begin{array}{l}\text { Liczba } \\
\text { próbek }\end{array}$ & $\%$ \\
\hline $\begin{array}{l}\text { Placówki kształcenia } \\
\text { ustawicznego }\end{array}$ & $\begin{array}{c}0 \% \\
(0 / 2) \\
\end{array}$ & 5 & $100.0 \%$ & & $0.0 \%$ & & $0.0 \%$ & & $0.0 \%$ \\
\hline $\begin{array}{l}\text { Placówki wychowania } \\
\text { pozaszkolnego }\end{array}$ & $\begin{array}{l}33 . \% \\
(1 / 3) \\
\end{array}$ & 9 & $90.0 \%$ & 1 & $10.0 \%$ & & $0.0 \%$ & & $0.0 \%$ \\
\hline międzyszkolne ośrodki sportowe & $\begin{array}{c}0 \% \\
(0 / 2)\end{array}$ & 7 & $100.0 \%$ & & $0.0 \%$ & & $0.0 \%$ & & $0.0 \%$ \\
\hline $\begin{array}{r}\text { młodzieżowe domy kultury } \\
\text { i pałace młodzieży }\end{array}$ & $\begin{array}{l}100 \% \\
(1 / 1)\end{array}$ & 2 & $66.7 \%$ & 1 & $33.3 \%$ & & $0.0 \%$ & & $0.0 \%$ \\
\hline $\begin{array}{l}\text { Placówki z pobytem } \\
\text { calodobowym }\end{array}$ & $\begin{array}{l}55.6 \% \\
(15 / 27)\end{array}$ & 71 & $64.6 \%$ & 31 & $28.2 \%$ & 8 & $7.3 \%$ & & $0.0 \%$ \\
\hline bursy i internaty & $\begin{array}{c}57.1 \% \\
(4 / 7) \\
\end{array}$ & 14 & $60.9 \%$ & 6 & $26.1 \%$ & 3 & $13.0 \%$ & & $0.0 \%$ \\
\hline domy studenckie & $\begin{array}{l}47.1 \% \\
(8 / 17)\end{array}$ & 45 & $67.2 \%$ & 17 & $25.4 \%$ & 5 & $7.5 \%$ & & $0.0 \%$ \\
\hline $\begin{array}{r}\text { młodzieżowe ośrodki } \\
\text { wychowawcze }\end{array}$ & $\begin{array}{l}100 \% \\
(1 / 1)\end{array}$ & 10 & $76.9 \%$ & 3 & $23.1 \%$ & & $0.0 \%$ & & $0.0 \%$ \\
\hline $\begin{array}{r}\text { specjalne ośrodki szkolno- } \\
\text { wychowawcze }\end{array}$ & $\begin{array}{l}100 \% \\
(2 / 2)\end{array}$ & 2 & $28.6 \%$ & 5 & $71.4 \%$ & & $0.0 \%$ & & $0.0 \%$ \\
\hline $\begin{array}{l}\text { Szkoły funkcjonujące } \\
\text { samodzielnie }\end{array}$ & $\begin{array}{l}42.9 \% \\
(18 / 47)\end{array}$ & 89 & $65.4 \%$ & 24 & $17.7 \%$ & 16 & $11.8 \%$ & 7 & $5.2 \%$ \\
\hline gimnazja & $\begin{array}{c}70 \% \\
(7 / 10) \\
\end{array}$ & 17 & $47.2 \%$ & 8 & $22.2 \%$ & 8 & $22.2 \%$ & 3 & $8.3 \%$ \\
\hline szkoły podstawowe & $\begin{array}{l}32.3 \% \\
(10 / 31)\end{array}$ & 72 & $75.0 \%$ & 12 & $12.5 \%$ & 8 & $8.3 \%$ & 4 & $4.2 \%$ \\
\hline szkoły policealne & $\begin{array}{c}100 \% \\
(1 / 1)\end{array}$ & & $0.0 \%$ & 4 & $100.0 \%$ & & $0.0 \%$ & & $0.0 \%$ \\
\hline Zespoły szkół & $\begin{array}{l}37.8 \% \\
(14 / 37) \\
\end{array}$ & 69 & $65.7 \%$ & 18 & $17.1 \%$ & 15 & $14.3 \%$ & 3 & $2.9 \%$ \\
\hline Suma końcowa & $\begin{array}{c}43.2 \% \\
(48 / 111)\end{array}$ & 243 & $66.4 \%$ & 74 & $20.2 \%$ & 39 & $10.7 \%$ & 10 & $2.7 \%$ \\
\hline
\end{tabular}




\section{DISCUSSION}

Research carried out in educational institutions in 2016 for the first time was carried out on such a large scale. As demonstrated by the analysis, the risk of $L e$ gionella sp. infection is real, taking into account the use of showers by the students after classes of physical activity. In addition, organized groups of adults and employees of these institutions also use the sports and sanitary infrastructure (10). A similar situation takes place in facilities with a 24-hour stay (boarding houses, dormitories), where young people live and regularly use shower. At present, it is not known whether the managers of the indicated educational institutions are monitoring the condition of the internal water supply network with regard to the colonization of Legionella $\mathrm{sp}$. The managers of these facilities and their users (children and adolescents) have no knowledge and awareness of the threat associated with colonizing the water network and health consequences. In the case of medical entities (hospitals, care and treatment institutions - ZOL) and social welfare homes (DPS), the State Sanitary Inspection has full current and historical documentation of research on the presence of Legionella sp. in the internal water supply network of these facilities. Analyzing the results of research conducted in these facilities in 2016 in the Małopolskie voivodship, it should be noted that in $32 \%$ of DPS facilities, $57.1 \%$ of hospitals and in $20 \%$ of ZOL the presence of Legionella sp. was found. In 2017, the number of exceedances found in these facilities was still similar: DPS - 35.2\%, hospitals - 49.1\%, ZOL - 29.4\% (11). Studies conducted in Greek hotels have shown that the risk of water contamination with Legionella sp. in pool showers is $16.42 \%$, in garden sprinklers $7.46 \%$, and in the pool water $5.97 \%$ (15). However, research conducted in Japan indicated that $64 \%$ of samples from households and 3\% from public entities, such as baths or hot springs, showed the presence of Legionella sp (12). It should be pointed out that the entire population is sensitive to infection with Legionella sp., however, the risk groups include people with immunocompromised persons, for example people after organ transplants, people with diabetes, neoplastic diseases, and chronic respiratory diseases. In addition, men and older people are more likely to be infected (13).

A systematic review of 47 studies published in 1981-2015 indicated that hot tubs, whirlpools and spa pools are an important source of infection with Legionella sp. A study of 1,079 cases of Legionella infection showed that $57.5 \%$ of cases were diagnosed as Pontiac fever (no deaths), and $42.5 \%$ as a legionella disease, including $6.3 \%$ of deaths (14).

In 1998-2005 in Poland the number of serologically confirmed cases of legionellosis in children aged
Tabela IV przedstawia odsetek obiektów pod względem obecności Legionella sp. wraz z oceną skażenia w poszczególnych kategoriach obiektów nauczania i wychowania. Pod względem stopnia skażenia (brak lub znikome, średnie, wysokie, bardzo wysokie - parametry określone w Tabeli I rozporządzenia (9)) największa liczba kwestionowanych próbek mieściła się w zakresie skażenia średniego (74 próbki), 39 próbek skażenia wysokiego i 10 próbek bardzo wysokiego (w 4 obiektach liczba stwierdzonych pałeczek Legionella sp. wyniosła $10000 \mathrm{jtk} / 100 \mathrm{ml}$ ). W 243 próbkach liczba Legionella sp. była znikoma lub bakterie nie występowały.

\section{DYSKUSJA}

Badania przeprowadzone w placówkach nauczania i wychowania w $2016 \mathrm{r}$. były pierwsze zrealizowane na tak szeroką salę. Zagrożenie zakażeniem pałeczkami Legionella sp. jest realne, biorąc pod uwagę korzystanie przez uczniów po zajęciach wychowania fizycznego z pryszniców. Ponadto z infrastruktury sportowej i sanitarnej korzystają również zorganizowane grupy osób dorosłych i pracownicy tych placówek (10). Podobna sytuacja ma miejsce w placówkach z pobytem całodobowym (internaty, akademiki), gdzie młodzi ludzie mieszkają i regularnie korzystają z natrysków. Obecnie nie wiadomo czy kierownicy wskazanych placówek nauczania i wychowania monitorują stan wewnętrznej sieci wodociagowej pod wzgledem kolonizacji Legionella sp. Zarządcy tych obiektów i ich użytkownicy (dzieci i młodzież) nie mają wiedzy i świadomości zagrożenia związanego ze skolonizowaniem sieci wodnej oraz konsekwencji zdrowotnych. W przypadku podmiotów leczniczych (szpitali, zakładów opiekuńczo-leczniczych - ZOL) oraz domów pomocy społecznej (DPS) Państwowa Inspekcja Sanitarna dysponuje pełną bieżącą i historyczną dokumentacją badań w zakresie obecności pałeczek Legionella sp. w sieci wewnętrznej wodociągowej tych obiektów. Analizując wyniki badań prowadzonych w tych obiektach w 2016 r. na terenie województwa małopolskiego należy zauważyć, że w 32\% obiektów DPS, 57,1\% szpitali i w 20\% ZOL stwierdzono obecność Legionelli sp. W 2017 r. liczba stwierdzonych przekroczeń, w tych obiektach była nadal podobna: DPS - 35,2\%, szpitale - 49,1\%, ZOL-29.4\% (11).

Badania przeprowadzone $\mathrm{w}$ greckich hotelach, wykazały, że ryzyko zanieczyszczenia wody pałeczkami Legionella w prysznicach basenowych wynosi $16,42 \%$, w tryskaczach ogrodowych $7,46 \%$, a w wodzie w basenie $5,97 \%$ (15). Natomiast badania prowadzone w Japonii, wskazały, iż w $64 \%$ próbek pochodzących z gospodarstw domowych i w $3 \%$ z podmiotów publicznych, takich jak łaźnie czy gorące źródła 
3-17 years was 13 cases (16). Among small patients diagnosed with legionellosis were patients with cancer, hospitalized for other basic diseases, but also healthy patients whose disease developed at home (17). Case study published in 2005 by Mrozińska showed that legionellosis can occur in children who are developing properly, healthy, without chronic diseases and is usually diagnosed late when the child goes to hospital in a serious condition. The source and causes of the infection are not described in the publication. In subsequent years 2006-2017 in Poland, the number of serologically confirmed cases of legionellosis in children aged 3-17 years amounted to 60 cases (18), which accounts for $24 \%$ of legionellosis cases in persons over 18 years of age in the period 2006-2017. In 2016, there were no reports of diseases caused by Legionella sp. in children in the Małopolskie voivodship. In adults, there were 2 cases of legionellosis. In Poland, in 2016, 27 cases of legionellosis were reported, including 25 cases of Legionnaires' disease and 2 cases of Pontiac fever, including 2 deaths of people aged 59 and 69 (19). In Polish literature there are no other publications that would report on the above issue. Also, there are no foreign reports on the occurrence of Legionella sp. in educational and upbringing facilities. The latest published article concerns risk assessment of Legionella sp. in recreational spaces, such as fountains, showers at swimming pools and spas, garden sprinklers in hotels, does not include teaching and education facilities (20). The media can find information about the occurrence of Legionella sp. infection in schools in different countries, among others in Great Britain, USA, Ireland (21, $22,23)$, however, there are no scientific studies analyzing the above topic. In 2018, a study was published in kindergartens, schools, sports buildings, office buildings and nursing homes in Norway regarding the assessment of the use of various methods, among others thermal disinfection and membrane filtration in the fight against Legionella pneumophila in urban shower systems. Active surveillance did not show a significant effect of the methods assessed and no significant positive correlation was found between the total heterotrophic number of platelets (heterotrophic bacteria index) and Legionella pneumophila concentration, and the risk of Legionella infection is assessed as low and uncertain (24). As part of the European Center for Disease Prevention and Control (ECDC), there is the European Legionnaires' Disease Surveillance Network (ELDSNet), whose role is to detect, control and prevention of individual cases, group infections and outbreaks of legionnaires' disease in EU / EEA countries, as well as assistance in other countries to this extent. As ECDC points out, the number of cases and group cases associated with staying in a hotel or other tourist accommodation increases $(25,26)$. In 2001, there stwierdzono obecność pałeczki Legionella sp (12). Należy wskazać, że cała populacja jest wrażliwa na zakażenie pałeczkami Legionella sp., jednakże do grup ryzyka można zaliczyć osoby z obniżoną odpornością np. osoby po przeszczepach narządów, osoby chore na cukrzycę, choroby nowotworowe, przewlekłe schorzenia układu oddechowego. Ponadto na zakażenie częściej narażeni są mężczyźni, oraz osoby starsze (13).

Przegląd systematyczny 47 badań opublikowanych w latach 1981-2015 wskazał, że wanny $\mathrm{z}$ hydromasażem, jacuzzi i baseny typu spa stanowią istotne źródło zakażenia bakteriami Legionella sp. Badanie obejmujące 1079 przypadków zakażenia Legionella wykazało, iż 57,5\% przypadków zostało zdiagnozowanych jako gorączka Pontiac (bez żadnych zgonów), a $42,5 \%$ jako choroba legionistów w tym $6,3 \%$ przypadków śmiertelnych (14).

W latach 1998-2005 w Polsce liczba potwierdzonych serologicznie przypadków legionelozy u dzieci w wieku 3-17 lat wyniosła 13 przypadków (16). Wśród małych pacjentów z rozpoznaną legionelozą byli chorzy z chorobą nowotworową, hospitalizowani z powodu innych chorób podstawowych, ale również pacjenci zdrowi, u których choroba rozwinęla się w domu (17). Analiza przypadków opublikowana w 2005 r. przez Mrozińska wykazała, że legioneloza może występować u dzieci prawidłowo rozwijających się, zdrowych, bez chorób przewlekłych i zazwyczaj diagnozowana jest późno, gdy dziecko trafia do szpitala w stanie ciężkim. W publikacji nie opisano źródła i przyczyn zakażenia. W kolejnych latach 2006-2017 w Polsce liczba potwierdzonych serologicznie przypadków legionelozy u dzieci w wieku 3-17 lat wyniosła 60 przypadków (18) (co stanowi $24 \%$ przypadków legionelozy u osób powyżej 18 roku życia w okresie 2006-2017). W 2016 r. w województwie małopolskim zgłoszeń chorób wywołanych bakterią Legionella sp. nie odnotowano u dzieci. U osób dorosłych odnotowano natomiast 2 przypadki legionelozy. W Polsce w 2016 r. zgłoszono 27 przypadków legionelozy, w tym 25 przypadków choroby legionistów i 2 przypadki gorączki Pontiac, w tym 2 zgony w wieku 59 i 69 lat (19).W literaturze polskiej brak jest innych publikacji, które dotykałyby powyższego zagadnienia. Również brak jest doniesień zagranicznych dotyczących występowania Legionella sp. w placówkach nauczania i wychowania. Najnowszy opublikowany artykuł dotyczy oceny zagrożenia Legionella $s p$. w przestrzeniach rekreacyjnych takich jak fontanny, prysznice przy basenach i spa, ogrodowych spryskiwaczach w hotelach, nie obejmuje obiektów nauczania i wychowania (20). W mediach można odnaleźć informacje o wystąpieniu zakażenia Legionella sp. w szkołach w różnych krajach $\mathrm{m}$. in. w Wielkiej Brytanii, USA, Irlandii $(21,22,23)$, jednakże brak jest naukowych opracowań analizujących powyższy temat. 
was an outbreak of Legionnaires' disease in Spain (27). Although there is an obligation in all EU / EEA Member States to report cases of Legionnaires' disease, it is likely that these data may be underestimated, especially in the case of passive surveillance, and the number of cases recorded increases systematically. In 2011-2015, 29 EU / EEA countries reported 30,532 cases of legionellosis to ECDC, of which $92.3 \%$ were confirmed cases. The number of confirmed cases increased from $90.6 \%$ in 2011 to $93.3 \%$ in 2015 . The increase in confirmed cases took place mainly in Poland (from 44\% in 2011 to $70 \%$ in 2015) as well as in Romania and Latvia. The highest age-adjusted maturity ratio in the EU / EEA countries was recorded in 20132014 and it amounted to $1.3 / 100000$ of the population. Registered cases in ECDC indicate that communityacquired infections $(70.7 \%)$ were most common, but also travel-related infections (19.9\%), and only $7.3 \%$ were hospital-acquired (28). This analysis indicates the existence of a problem that has not been explored in detail so far. Due to the lack of research addressing Legionella sp. in earlier years, as well as the lack of available data from other voivodships or other European countries, the authors were not able to make a comparative assessment.

\section{CONCLUSIONS}

The conducted research has shown that it is reasonable to monitor the presence of Legionella sp. in water networks of public facilities (teaching and upbringing facilities). In $33.6 \%$ of samples taken, water quality was not consistent with the requirements, and in $2.7 \%$ of samples the number of Legionella sp. bacteria found was $\geq 10,000$ $\mathrm{cfu} / 100 \mathrm{ml}$, which means very high contamination. Pollution of the internal water network was found in $43.2 \%$ of the inspected facilities, therefore it is necessary to take measures to reduce the colonization of Legionella sp. and their multiplication in the network. The cyclic control of water quality is therefore justified. Despite the statement in the above objects that are subject to the analysis of the presence of Legionella sp., in 2016 in the Małopolskie voivodship there were no reports of diseases caused by this disease agent in children. No reports clearly indicate that the Legionnaires' disease or Pontiac fever has not occurred and may result from incomplete diagnosis in this direction $(29,30)$. In 2016, only 3 urine specimens (patients tested for Legionella infection) were provided to the Laboratory for Bacteriological Serological Diagnostics in the Department of Bacteriology of NDAP-PZH to determine the presence of legionella antigen (all turned out to be negative) and 121 serum samples (in 14 samples antibodies were detected at a diagnostically significant level). This suggests that during treatment of cases of pneumonia, the legionella infection and attempts to es-
W 2018 r. opublikowano badanie przeprowadzone w przedszkolach, szkołach, budynkach sportowych, budynkach biurowych oraz domach opieki w Norwegii dotyczące oceny zastosowania różnych metod $\mathrm{m}$. in. dezynfekcji termicznej i filtracji membranowej w zwalczaniu Legionella pneumophila w miejskich systemach prysznicowych. Aktywny nadzór nie wykazał istotnego wpływu ocenianych metod oraz nie stwierdzono istotnej dodatniej korelacji między stężeniem całkowitej heterotroficznej liczby płytek (wskaźnik obecności bakterii heterotroficznych) a stężeniem Legionella pneumophila, a ryzyko zakażenia pałeczkami Legionella ocenia się jako niskie i niepewne (24). W ramach Europejskiego Centrum ds. Zapobiegania i Kontroli Chorób (ang. European Centre for Disease Prevention and Control, ECDC) funkcjonuje Europejska Sieć Nadzoru na Chorobą Legionistów (ang. European Legionnaires' Disease Surveillance Network, ELDSNet), której rolą jest wykrywanie, kontrola i zapobieganie pojedynczym przypadkom, zakażeniom grupowym i ogniskom choroby legionistów w krajach UE/EOG, jak i pomoc w powyższym zakresie innym krajom. Jak wskazuje ECDC wzrasta liczba przypadków i zachorowań grupowych związanych z pobytem w hotelu lub innym miejscu zakwaterowania turystycznego (25, 26). W 2001 r. doszło do wybuchu epidemii choroby legionistów w Hiszpanii (27). Pomimo, że we wszystkich krajach członkowskich UE/EOG istnieje obowiązek zgłaszania przypadków choroby legionistów, to przypuszczalnie dane te mogą być niedoszacowane, szczególnie w przypadku nadzoru biernego, a liczba stwierdzonych przypadków wzrasta systematycznie. W latach 2011-2015 29 krajów UE/EOG zgłosiło 30 532 przypadki legionelozy do ECDC, spośród których $92,3 \%$ stanowiły przypadki potwierdzone. Liczba potwierdzonych przypadków wzrosła z 90,6\% w $2011 \mathrm{r}$. do 93,3\% w 2015 r. Wzrost przypadków potwierdzonych nastąpił głównie w Polsce (z 44\% w 2011 r. do 70\% w 2015 r.) a także, w Rumunii oraz na Łotwie. Najwyższy wskaźnik zapadalności skorygowany o wiek w krajach UE/EOG odnotowano w latach 20132014 i wynosił on 1,3/100 000 ludności. Rejestrowane przypadki w ECDC wskazują, że najczęściej odnotowywano zakażenia pozaszpitalne $(70,7 \%)$, ale także zakażenia związane z podróżą (19,9\%), a jedyne 7,3\% były zakażeniami szpitalnymi (28).

Niniejsza analiza wskazuje na istnienie problemu, który nie został do tej pory szczegółowo zgłębiony. Ze względu na brak prowadzenia badań w kierunku Legionella sp. w zakładach nauczania i wychowania w latach wcześniejszych, a także brak dostępnych danych z innych województw lub innych krajów europejskich, autorzy nie mieli możliwości dokonania oceny porównawczej. 
tablish the etiological factor are not considered too often (31) - no laboratory tests for Legionella sp. the presented data indicate a significant under-registration of cases of legionellosis (32), independently from the age of the patient.

\section{REFERENCES}

1. Atlas RM, Legionella: From environmental habitats to disease pathology, detection and control. Environ Microbiol, 1999; 1: 283-293.

2. Nguyen ML, Yu VL: Legionella infection. Clin Chest Med 1991; 12: 257-268.

3. Alexandropoulou IG, Konstantinidis TG, Parasidis TA, et al., First report of Legionella pneumophila in car cabin air filters. Are these a potential exposure pathway for professional drivers? Scand J Infect Dis 2013; 45(12): 948-52

4. Schwake DO, Alum A, Abbaszadegan M, Automobile windshield washer fluid: A potential source of transmission for legionella. Sci Total Environ 2015; 526, 271-277

5. Euser S, Jong S, Bruin JP, et al., Legionnaires' disease associated with a car wash installation. Lancet 2013; 382 (9910), DOI: https://doi.org/10.1016/S01406736(13)62188-1 (dostęp: 30.11.2018 r.)

6. Palusińska-Szysz M, Cendrowska-Pinkosz M, Występowanie i chorobotwórczość bakterii z rodziny Legionellaceae. Postepy Hig Med Dosw 2008; 62: 337 353

7. Tabela E, załącznik nr 1 Rozporządzenia Ministra Zdrowia z dnia 13 listopada 2015 r. w sprawie jakości wody przeznaczonej do spożycia przez ludzi (Dz.U. 2015 poz. 1989)

8. Rozporządzenie Ministra Zdrowia $\mathrm{z}$ dnia 13 listopada 2015 r. w sprawie jakości wody przeznaczonej do spożycia przez ludzi (Dz.U. 2015 poz. 1989)

9. Rozporządzenie Ministra Zdrowia z dnia 13 listopada 2015 r. w sprawie jakości wody przeznaczonej do spożycia przez ludzi (Dz.U. 2015 poz. 1989)

10. https://www.nj.com/essex/index.ssf/2018/09/bacteria_that_causes_legionnaires_disease_found_in_9 schools_airport_hotel.html [dostęp 4.02.2018]

11. System Woda Excel - materiały Wojewódzkiej Stacji Sanitarno-Epidemiologicznej w Krakowie, z dnia 26.10.2018 r.

12. Kobayashi M, Oana K, Kawakami Y., Bath water contamination with Legionella and nontuberculous mycobacteria in 24-hour home baths, hot springs, and public bathhouses of Nagano Prefecture, Japan. Jpn J Infect Dis, 2014; 67(4): 276-81.

13. Legionella czai się w instalacjach. https://www.mp.pl/ pacjent/pulmonologia/aktualnosci/81010,legionellaczai-sie-w-instalacjach [dostęp 29.11.2018]

14. Leoni E, Catalani F, Marini S, et al., Legionellosis associated with recreational waters: a systematic review of cases and outbreaks in swimming pools, spa pools, and similar environments. Int J Environ Res Public Health 2018; 15(8), https://doi.org/10.3390/ijerph15081612 (dostęp: 30.11.2018 r.)

\section{WNIOSKI}

Przeprowadzone badania wykazały, że zasadne jest monitorowanie obecności pałeczek Legionella sp. w sieciach wodnych obiektów użyteczności publicznej (obiektów nauczania i wychowania). W 33,6\% pobranych próbek stwierdzono niezgodność jakości wody z wymaganiami, a w $2,7 \%$ próbek liczba stwierdzonych pałeczek Legionella sp. wyniosła $\geq 10000$ jtk/100 $\mathrm{ml}$, co oznacza skażenie bardzo wysokie. Stwierdzono zanieczyszczenie wewnętrznej sieci wodnej w 43,2\% skontrolowanych obiektów, dlatego konieczne jest podjęcie działań zmierzających do ograniczenia kolonizacji pałeczekami Legionella sp. i ich namnażania w sieci. Uzasadniona jest zatem cykliczna kontrola jakości wody.

Pomimo stwierdzenia w ww. obiektach będących przedmiotem analizy obecności bakterii Legionella sp. nie odnotowano w 2016 r. w województwie małopolskim zgłoszeń chorób wywołanych tym czynnikiem chorobotwórczym u dzieci. Brak zgłoszeń nie wskazuje jednoznacznie na to, że choroba legionistów lub gorączka Pontiac nie wystąpiły i wynikać może z prowadzenia niepełnej diagnostyki w tym kierunku(29, 30). W 2016 r. do Pracowni Diagnostyki Serologicznej Zakażeń Bakteryjnych w Zakładzie Bakteriologii NIZP-PZH dostarczono tylko 3 próbki moczu (chorych badanych w kierunku zakażenia Legionella) dla określenia obecności antygenu legionelozowego (wszystkie okazały się ujemne) oraz 121 próbek surowicy (w 14 próbkach wykryto przeciwciała na poziomie znamiennym diagnostycznie). Sugeruje to, że podczas leczenia przypadków zapaleń płuc, zbyt rzadko łączone są one z zakażeniem bakterią Legionella, oraz braku podjęcia próby ustalenia czynnika etiologicznego (31) brak badań laboratoryjnych w kierunku Legionella sp. Przedstawione dane wskazują na znaczące niedorejestrowanie przypadków choroby legionelozy (32) niezależnie od wieku pacjenta.

15. Papadakis A, Chochlakis D, Sandalakis V, et al., Legionella spp. risk assessment in recreational and garden areas of hotels, Int J Environ Res Public Health 2018; 15(4), https://doi.org/10.3390/ijerph15040598 (dostęp 30.11.2018 r.)

16. Mrozińska M, Zapalenie płuc o etiologii Legionella Pneumophila (LP) u trojga dzieci - opis przypadków. Przegl Epidemiol 2005; 59: 851-857

17. Pancer K, Stypułkowska Misiurewicz H, Epidemiology of Legionella infection among children examined in Poland in 1998-2005, 20 ${ }^{\text {th }}$ Annual meeting of European Working Group for Legionella Infections (abstract book), Istituto Superiore di Sanità, Rome, May 16-17, 2005

18. Narodowy Instytut Zdrowia Publicznego - Państwowy Zakład Higieny (dostęp 22.08.2018 r.) 
19. Stypułkowska-Misiurewicz H, Czerwiński M, Legionellosis in Poland in 2016. Przegl Epidemiol 2018; 72(2): 143-147.

20. Papadakis A, Chochlakis D, Sandalakis V, et al., Legionella spp. risk assessment in recreational and garden areas of hotels. Int J Environ Res Public Health 2018;15(4), https://doi.org/10.3390/ijerph15040598 (dostęp 30.11.2018 r.)

21. https://www.theguardian.com/education/2006/mar/09/ schools.uk1 (dostęp 23.08.2018)

22. https://edition.cnn.com/2015/09/23/health/legionnaires-disease-schools-closed/index.html (dostęp 23.08.2018)

23. https://www.bbc.co.uk/news/uk-northern-ireland-21319048 (dostęp 23.08.2018)

24. Wiik R, Krøvel AV, Necessity and effect of combating Legionella pneumophila in municipal shower systems. Plos One 2014; 9(12) https://doi.org/10.1371/journal. pone.0114331(dostęp 30.11.2018)

25. Nguyen TM, Ilef D, Jarraud S et al. A community-wide outbreak of Legionnaires disease linked to industrial cooling towers-how far can contaminated aerosols spread. J Infect Dis 2006; 193(1): 102-11.

26. European Centre for Disease Prevention and Control. European Legionnaires' Disease Surveillance Network (ELDSNet) Operating procedures for the surveillance of travel associated Legionnaires' disease in the EU/ EEA, Stockholm: ECDC; 2017

27. Ricketts KD, Joseph CA, Travel associated Legionnaires' disease in Europe: 2006. Eurosurveillance 2008; 13 (29), https://doi.org/10.2807/ese.13.29.18930-en (dostęp: 15.12.2018 r.).
28. Julien B, On behalf of the European Legionnaires' Disease Surveillance Network, Legionnaires' disease in Europe, 2011 to 2015, Eurosurveillance 2017; 22(27 https://doi.org/10.2807/1560-7917.ES.2017. 22.27.30566 (dostęp: 15.12.2018 r.)

29. Lepine L A. et al, A recurrent outbreak of nosocomial legionnaires' disease detected by urinary antigen testing: evidence for long-term colonization of a hospital plumbing system, Infect Control Hosp Epidemiol 1998; 19: 905-910.

30. Stypułkowska-Misiurewicz H, Czerwiński M, Legionellosis in Poland in 2015.Przegl Epidemiol 2017; 71(3): 333-337

31. Stypułkowska-Misiurewicz H, Czerwiński M, Legionellosis in Poland in 2014 roku. Przegl Epidemiol 2016; 70(2): 203-207

32. Stypułkowska-Misiurewicz H, Czerwiński M, Legionellosis in Poland in 2016 Przegl Epidemiol 2018; 72(2): 143-147

Received: 12.02.2019

Accepted for publication: 28.02.2019

Otrzymano: 12.02.2019 r.

Zaakceptowano do publikacji: 28.02.2019 r.

\section{Address for correspondence: \\ Autor do Korespondencji:}

Małgorzata Bała

Address: Department of Hygiene and Dietetics, Jagiellonian University - Collegium Medicum ul. Kopernika 7, 31-034 Cracow e-mail: malgorzata.1.bala@uj.edu.pl 